\title{
INNOCENT SUFFERING IN MESOPOTAMIA
}

\author{
Daniel P. Bricker
}

\begin{abstract}
Summary
Recent discussion of Mesopotamian texts holds to the idea that theodicy is present in this literature. An examination of the material which takes into account the cultural and religious views prevalent at the time will call into question the validity of classifying certain documents as theodicy. This study will attempt to evaluate the application of the term theodicy to the pertinent literature recovered from Mesopotamia thus far.
\end{abstract}

\section{Introduction: The Purpose of the Study}

Studies of the literature from ancient Mesopotamia concerned with the idea of innocent suffering and theodicy have continued to hold to the notion that the concept of an innocent sufferer existed in ancient Mesopotamia. This is seen in the title that modern scholarship has bestowed on one of the documents ${ }^{1}$ as well as the pervasive view of scholars who discuss other documents that contain similar motifs and themes.

This study will examine the issue of innocent suffering in the literature of Mesopotamia to analyse the pertinent materials with respect to the concept of theodicy. Ancient Israel's literature will be mentioned only in passing, but it is hoped that this study will shed light on that topic as it appears in the Old Testament.

Wolfram von Soden has listed four basic elements which must be present for the question of theodicy to be raised:

(1) a clear sense of right and wrong, so that a sufferer could reasonably claim to be suffering undeservedly;

1 This document is the so-called Babylonian Theodicy; see the translation by B.R. Foster in W.W. Hallo and K. Lawson Younger, Jr., ed., The Context of Scripture (3 vols.; Leiden: Brill, 1997-1999), 1.492-95. Foster's translation may also be seen in his Before the Muses (2 vols.; Bethesda: CDL Press, 1993), 2.806-814. 
(2) significant individual worth, so that personal suffering must be justified;

(3) minimal competition within the godhead or pantheon, so that suffering cannot be blamed on one deity due to human loyalty to another; and

(4) a limited view of judgement in the afterlife. ${ }^{2}$

If any of these four elements is absent, the tension which generally leads to a theodicy can be relieved. This is because the absence of any one of these components can negate or qualify the principle of equitable or just retribution. The presence of these four factors in any given situation may not answer the question of suffering but it allows the deity to be absolved of responsibility and therefore accusations of divine injustice are no longer appropriate. ${ }^{3}$ It is my contention that the texts from Mesopotamia do not contain theodicy in the modern sense. ${ }^{4}$ Gods or goddesses were rarely blamed for human suffering. Sin was virtually always seen as the cause of human suffering. Thus the issue of divine justice rarely surfaced in Mesopotamia.

\section{The Mesopotamian Cultural and Religious Background}

Mesopotamian deities were personifications of various aspects of reality, 5 and guided the world according to their purposes and laws. ${ }^{6}$ They often displayed characteristics such as spite, lust and rage, and sometimes there was contention between various gods due to competing purposes. They were members of a 'divine assembly' 7 which sought to determine a common course. The interests of the

2 W. von Soden, 'Das Fragen nach der Gerechtigkeit Gottes im Alten Orient', Mitteilungen der deutschen Orient-Gesellschaft 96 (1965), 41-59; cf. J.H. Walton, Ancient Israelite Literature in Its Cultural Context (rev. ed.; Grand Rapids: Zondervan, 1990), p. 180.

3 Walton, p. 180.

4 For general discussions of this term see J.L. Crenshaw, 'Theodicy', in D.N. Freedman, ed., Anchor Bible Dictionary (6 vols.; New York: Doubleday \& Co., 1992), 6.444-47; and J.S. Feinberg, 'Theodicy', in W. Elwell, ed., Evangelical Dictionary of Theology (Grand Rapids: Baker, 1984), 1083-86.

5 G. Buccellati, 'Wisdom and Not: The Case for Mesopotamia', JAOS 101 (1981), 36.

6 S.N. Kramer, The Sumerians: Their History, Culture and Character (Chicago: University of Chicago Press, 1963), p. 113.

7 E.T. Mullen, Jr., 'Divine Assembly', in Anchor Bible Dictionary 2.214-17. 
gods ran roughly parallel to those of humanity, since humans were created for the purpose of serving the gods:

I shall compact blood, I shall cause bones to be,

I shall make stand a human being, let 'Man' be its name.

I shall create humankind,

They shall bear the gods' burden that those may rest. ${ }^{8}$

This view of humanity was more a reflection of their society than their theology:

In the Sumerian city-state,...the characteristic and most significant organization was the temple-estate, in which thousands of people cooperated in works of irrigation and agriculture in a politico-economic system centered on the temple, with all these people thought of as the servants of the god. The myth of the creation of man, therefore, was not basically a comment on the nature of man but an explanation of a particular social system, heavily dependent upon communal irrigation and agriculture, for which the god's estates were primary foci of administration. ${ }^{9}$

The gods needed people to feed and care for them through the sacrifices and cult.

The lot in life for the average person was to be quiet, ${ }^{10}$ keep the land in good order and attend to the needs of the gods, yet the number of requests for divine intervention show that the purposes of the gods were not clearly discernible. The plans or principles which kept the cosmos running smoothly were designated by the Sumerian word $M E$,

8 Enūma elish VI.5-8; cf. also VI.33-34. This poem has been so named following the Akkadian text of the opening line of the poem (see Hallo and Younger, 1.400401), there called the Epic of Creation. Much the same attitude was taken during the Old Babylonian period in the Atrahasis epic; see W.G. Lambert and A.R. Millard, Atra-hasis: The Babylonian Story of the Flood (Oxford: Clarendon, 1969), p. 59. A recent translation of Atrahasīs is found in Hallo and Younger, 1.450-52.

9 H.W.F. Saggs, Encounter with the Divine in Mesopotamia and Israel (London: Athlone, 1978), p. 168. Saggs believes this is what gave the Mesopotamians their dignity and self worth (p. 170).

10 K. van der Toorn, Sin and Sanction in Israel and Mesopotamia (Assen: Van Gorcum, 1985), p. 4. Atrahasīs gives the reason for destroying mankind in a flood as 'noise'. The debate over the term rigmu has a bearing on whether the flood was justified by human sin, or whether humans were merely a nuisance. It has been suggested that the noise which disturbed Enlil was a metaphoric reference to wicked behavior; see R. Oden, 'Divine Aspirations in Atrahasis and in Genesis 111 ', ZAW 93 (1981), 197-216; thus the need to keep 'quiet'. Population control is another possibility suggested by A.D. Kilmer, 'The Mesopotamian Concept of Overpopulation and Its Solution as Reflected in the Mythology', Orientalia 41 (1972), 160-77, though it seems population control was the solution, not the problem. See the discussion of W.L. Moran, 'Some Considerations of Form and Interpretation in Atra-Hasis', in F. Rochberg-Halton, ed., Language, Literature, and History: Philological and Historical Studies Presented to Erica Reiner (AOS 67; New Haven: AOS, 1987), pp. 245-55. 
the exact meaning of which is still uncertain." These divinely ordained decrees covered over one hundred aspects of human life and civilisation, though many are still obscure in meaning due to the fragmentary nature of the texts where they are listed, translation problems, and the difficulty inherent in attempting to understand a culture that has not existed for over three thousand years. ${ }^{12}$ Thus individuals were concerned to live according to the divine order that regulated virtually all areas of life. 13

For the ordinary human the more prominent deities seemed remote and unapproachable, thus the main focus in religion had to do with personal gods, who were seen as intercessors between a worshipper and the great gods. ${ }^{14}$ The personal god was closely involved with an individual's success or failure, and was often viewed or addressed as a parent. Under this metaphor the god was seen in four ways: (1) the physical aspect (the father as engenderer of a child or the mother who gave birth), (2) the provider aspect, (3) the protector and intercessor, and (4) the claim parents have upon children for honour and obedience. ${ }^{15}$

The parental metaphor made the powers of the gods less threatening, and this ultimately led to the paradox of the righteous sufferer in Mesopotamian literature. The personal deities were often portrayed in a positive light, yet when misfortune came the only way of determining what offended a god was by divination or by trial-anderror. ${ }^{16}$ This is evident in dingir. sà.dib.ba texts:

11 Kramer, The Sumerians, p. 115. A list of the discernible portions of the MEs is on p. 116.

12 For a discussion of $M E$, see G. Farber-Flügge, Der Mythos 'Inanna und Enki' unter besonderer Berücksichtigung der Liste der me (Rome: Pontifical Biblical Institute, 1973). This book lists previous discussions (p. 116, n. 121); also W.W. Hallo and J.J.A. van Dijk, The Exaltation of Inanna (New Haven: Yale University Press, 1968), pp. 49-50 for Hallo's view, which is that a $M E$ represents a divine attribute.

13 See J. Gray, 'The Book of Job in the Context of Near Eastern Literature', $Z A W$ 82 (1970), 251-52.

14 For a discussion of the personal gods see T. Jacobsen, The Treasures of Darkness: A History of Mesopotamian Religion (New Haven: Yale University Press, 1976), pp. 147-64; and H. Vorländer, Mein Gott: Die Vorstellungen vom persönlich Gott im Alten Orient und im Alten Testament (AOAT 23; NeukirchenVluyn: Neukirchener Verlag, 1975).

15 Jacobsen, Treasures of Darkness, p.'158.

16 Van der Toorn, pp. 94-97; see also Walton, p. 153. Determining the offense was often attempted by reciting the Surpu incantations; see E. Reiner, Surpu: $A$ Collection of Sumerian and Akkadian Incantations (AfO 11; Graz: [n.p.], 1958). 
My god, I did not know how severe your punishment is.

I frivolously took a solemn oath in your name,

I profaned your decrees, I went too far,

l.... your mission in trouble,

I transgressed your way much,

I did not know, much .[...

My iniquities are many: I know not what I did. ${ }^{17}$

The last line shows both parts of the theological problem faced by a suffering person: the assumption of guilt and an ignorance of the offence.

To the Mesopotamians there was no sharp distinction between the care of the body and care of the soul, as opposed to modern societies in which religious faith and scientific medical practice are often viewed as mutually exclusive categories. ${ }^{18}$ Illness or misfortune often had mysterious causes. Speaking of debilitating illness, Brown says:

If one lost one's health and vigor one became a burden to both family and society, apparently suffering from divine disfavor as well. Thus it was crucial that the deity's favor be incurred and his or her help secured. To the ancient Near Eastern-and biblical!-mind, it was impossible to countenance a major god/God who did not heal. ${ }^{19}$

Another factor in the problem of suffering is that of the human element in healing, i.e. those who practised medicine. Magical arts and divination were the methods used to diagnose the cause of the illness. Appropriate incantations or other kinds of treatment were prescribed to alleviate the suffering by appeasing the offended deity. The two most frequent terms referring to those who practised the medical art were the ašipu and asû́. ${ }^{20}$ Treatment most often included herbs, plants, animal parts, etc., mixed with carriers such as beer, vinegar, honey, or tallow, and introduced into the patient's body by means of ingestion, enema or suppository. Other treatments consisted of topical lotions or salves. ${ }^{21}$

17 W.G. Lambert, 'DINGIR.Š̀.DIB.BA Incantations', JNES 33 (1974), 275, lines 23-29. The expression dingir.šà.dib.ba refers to 'appeasing an angry god'.

18 M.L. Brown, Israel's Divine Healer (Grand Rapids: Zondervan, 1995), p. 54; cf. J.W. Provensha, M.D., 'The Healing Christ', in M. Kelsey, ed., Healing and Christianity (New York: Harper \& Row, 1973), pp. 361-64.

19 Brown, p. 53 (his emphasis).

20 E.K. Ritter, 'Magical-expert (=ašipu) and Physician (=asû): Notes on Two Complementary Professions in Babylonian Medicine', in H. Guterbock and T. Jacobsen, ed., Studies in Honor of Benno Landsberger on His 75th Birthday (Chicago: University of Chicago Press, 1965), pp. 301-302. For more discussion of these two professions see Brown, pp. 40-43; and A.L. Oppenheim, Ancient Mesopotamia: Portrait of a Dead Civilization (rev. ed. E. Reiner; Chicago: University of Chicago Press, 1977), pp. 288-305.

21 Oppenheim, p. 292. 
Mesopotamian medicine shows a highly developed internal system which integrated folk-belief, cult ritual, and prescribed treatment. ${ }^{22}$ However, it shows change over time, with the asû falling out of use in favour of the ašipu, so one should not expect to see both offices featured prominently in all medical texts. ${ }^{23}$

\section{An Analysis of Pertinent Sumerian and Akkadian Literature}

\section{Sumerian Literature}

(1) 'Man and His God'.24 Since humanity was created to serve the gods $^{25}$ and blessings and prosperity gained thereby, the penitent sufferer in the poem confesses his sin and guilt in the hope that his misfortune will be reversed. However, there is no mention of a specific transgression and the sin is never explicitly stated.

In general, offence to the gods, or sin, was more often seen in terms of the cult and the rituals associated with it. ${ }^{26}$ Moral evil does not seem to have been experienced in any way other than when it was reduced to the 'pain of suffering' by the victims. ${ }^{27}$ In 'Man and His God' this seems to be the case, since the confession of guilt never goes beyond generalisation. The only proper recourse the supplicant had 'was not to argue and complain in the face of seemingly unjustifiable misfortune, but to plead and wail, lament and confess,

22 See Brown, pp. 42-43, and his documentation.

23 For a brief history of Mesopotamian medicine see Oppenheim, pp. 288-305; and J.V. Kinnier Wilson, 'Medicine in the Land and Times of the Old Testament', in T. Ishida, ed., Studies in the Period of David and Solomon and Other Essays (Winona Lake: Eisenbrauns, 1982), pp. 347-58.

${ }^{24}$ An outline and introduction is in S.N. Kramer, "Man and His God": A Sumerian Variation on the Job Motif', in M. Noth and D.W. Thomas, ed., Wisdom in Israel and the Ancient Near East (VTS 3; Leiden: Brill, 1955), pp. 170-82.

${ }^{25}$ See above; also Kramer, The Sumerians, p. 123; and T. Jacobsen, 'Mesopotamia', in H. Frankfort et al., The Intellectual Adventure of Ancient Man (Chicago: University of Chicago Press, 1946; repr. Phoenix Books, 1977), pp. 182, 185.

26 Some see the Mesopotamian idea of sin tied to ritual offences; see G.R. Driver, 'The Psalms in Light of Babylonian Research', in D.C. Simpson, ed., The Psalmists (London: Oxford University Press, 1926), p. 136; while more recently, others have pointed out the exceptions to this, e.g. Saggs, Encounter, p. 117.

27 J. Bottéro, 'The Problem of Evil in Mesopotamian Mythology and Theology', in Y. Bonnefoy, ed., Mythologies (rev. W. Doniger; 2 vols.; Chicago: University of Chicago Press, 1991), 1.162. 
his inevitable sins and failings. ${ }^{28} \mathrm{~A}$ pointed statement in this regard is found in lines 102-103:

Never has a sinless child

been born to its mother,

A mortal(?) has never been perfect(?),

a sinless man has never existed from old... ${ }^{29}$

This belief in original and universal sin provided a solution to the problem of suffering without challenging the justice of the gods, thus removing this poem from the ranks of theodicy. ${ }^{30}$ W.G. Lambert has stated that 'Man and His God' should not be considered part of the wisdom literature genre because the sufferer confessed sins while asking for release from his sufferings, apparently in the belief that this was more a confession than a struggle over questions regarding evil and the innocent, since it never questions divine justice. ${ }^{31}$ Since there is none without guilt there is no innocent sufferer, only an ignorant one.

Apparently belief in mankind's inherent sinfulness was enough to account for the misfortunes and sickness the writer begged to have relieved. The belief in general human sinfulness 32 negated any objections a human might raise. The predicament of being 'guilty as charged' had the disadvantage of not knowing what the charge was. Sufferers had to throw themselves on the mercy of the gods hoping to gain a positive hearing, since the divine will was often inscrutable. ${ }^{33}$

(2) Letter-prayers. ${ }^{34}$ In the view of the Mesopotamians, if a personal god was angry with an individual, a sacrifice and the

28 Kramer, The Sumerians, pp. 125-26.
29 Hallo and Younger, 1.574.
30 Von Soden, 'Das Fragen', p. 46.
31 W.G. Lambert, 'Some New Babylonian Wisdom Literature', in J. Day, R.P. Gordon, and H.G.M. Williamson, ed., Wisdom in Ancient Israel (Cambridge: Cambridge University Press, 1995), pp. 30-31.

32 H-P. Müller, 'Keilschriftliche Parallelen zum biblischer Hiobbuch: Möglichkeit und Grenze des Vergleichs', Orientalia 47 (1978), 369.

33 This is a brief statement of a more complex situation; see Kramer, The Sumerians, p. 126; and in more detail, G.L. Mattingly, 'The Pious Sufferer: Mesopotamia's Traditional Theodicy and Job's Counselors', in W.W. Hallo, B.W. Jones, and G.L. Mattingly, ed., The Bible in the Light of Cuneiform Literature (Lewiston: Mellen, 1990), pp. 313-18.

34 This genre of literature is so named by W.W. Hallo, 'Individual Prayer in Sumerian: The Continuity of a Tradition', JAOS 88 (1968), 76. He also observes that the letters are not always addressed to a god, but might also be addressed to the king, a king's servant, or a deified king who was deceased but addressed as 'my god'. Some letter-prayers are addressed to private individuals, or at most to officials (pp. 76-77). 
appropriate ritual was necessary to appease the divine anger. Sacrifices were carried out in the various temples dedicated to the gods. But what if, as Jacobsen asks, the god is not present when the supplicant presents a sacrifice to appease the god's anger? Or what if the person is too sick to travel to the temple to present prayers and sacrifices? ${ }^{35}$ The answer was to send a letter to the god which was placed near the statue of the deity, relieving the supplicant of the need to appear personally before the god. ${ }^{36}$ This method of communication with deities was ancient and widespread in Mesopotamia. ${ }^{37}$

Many of these letters have been recovered and they follow a similar pattern. They begin with a salutation to the divinity followed by the message and a conclusion. The body of the letter has no recognisable structural divisions but most of the contents express complaints, protests, prayers and formal reinforcements of the appeal, though not always in this order. ${ }^{38}$

One of the longest of these letters is one addressed to Enki, the personal god of Sin-šamuh, son of Ur-Nim. ${ }^{39} \mathrm{He}$ complains of attacks by a hostile deity (line 15) despite his loyalty and proper observance of the offerings at the festivals (lines 11-12). Although he has no question of his guilt (line 17), no omen has revealed the nature of his offence (line 14). Following a list of complaints regarding his physical condition and treatment by contemporaries he vows to dwell in the 'gate of Guilt-Absolved', and worship his god (lines 46-56) when the $\sin$ is cleansed.

As in 'Man and His God', there is no specific sin referred to, only a conviction on the part of the penitent worshipper that he was guilty. At worst, the blame is placed on a hostile deity for the illness and the supplicant pleads for his personal god to intervene.

Another possibility was to enlist the aid of a more powerful god, as seen in another letter-prayer:

\footnotetext{
35 Jacobsen, 'Mesopotamia', p. 205.

36 These prayers were originally inscribed on a valuable object belonging to the worshipper, but economic factors eventually led to the development of this literary genre, and letters were deposited, rather than inscribed objects, according to W.W. Hallo, Origins: The Ancient Near Eastern Background of Some Modern Western Institutions (Leiden: Brill, 1996), pp. 232-33.

37 See W.W. Hallo, 'Two Letter-Prayers to Amurru', in M. Lubetski, C. Gottlieb, and S. Keller, ed., Boundaries of the Ancient Near Eastern World: A Tribute to Cyrus Gordon (JSOTSS 273; Sheffield: Sheffield Academic Press, 1998), pp. 401405.

38 Hallo, Origins, pp. 233-34; 'Individual Prayer in Sumerian', pp. 76-77.

39 Hallo, 'Individual Prayer in Sumerian', p. 85, lines 1, 8.
} 
To the god my father speak; thus says Apil-Adad, your servant:

'Why have you neglected me (so)?

Who is going to give you one who can take my place?

Write to the god Marduk, who is fond of you,

That he may break my bondage;

Then I shall see your face and kiss your feet!

Consider also my family, grownups and little ones;

Have mercy on me for their sakes, and let your help reach me. ${ }^{40}$

Apil-Adad calls on his personal god to act on his behalf since mankind exists to serve the gods. The logic is impeccable. If the personal god allows Apil-Adad to remain indisposed for an extended period, or to die, then there will be one less person to serve the needs of the personal god. There is also the pleading for the personal god to consider the needs of the worshipper as well. He points out all the other members of his family who depend on him. The case is argued that a failure on the part of the gods to restore this man to health will have dire consequences not only on the man's family but on the gods themselves.

To sum up, in the traditional definitions of theodicy ${ }^{41}$ one seeks to justify the ways of God (or a god) when faced with suffering that is seemingly undeserved. It is an attempt to remove the contradictions in a theological system that holds to a doctrine of a benevolent deity and acknowledges the possibility of undeserved suffering. In my view Mattingly's claim that 'Man and His God' should retain the classification of theodicy fails to convince, since there is no claim to innocence by Mesopotamians when faced with misfortunes and/or sickness. The very opposite almost always holds true. Guilt is assumed, and the prayers are characterised by confession of sin and guilt in generalised terms to cover all possibilities, since humans are seen as inherently sinful.

\section{Akkadian Literature}

(1) The Pious Sufferer or Dialogue between a Man and His God. ${ }^{42}$ After the introduction (lines 1-11) the sufferer claims his affliction is due to no known sin:

40 M. Stol, Letters from Yale (Altbabylonische Briefe in Umschrift und Übersetzung Heft 9; Leiden: Brill, 1981), p. 141; Jacobsen, 'Mesopotamia', pp. 205-206.

41 See Mattingly's discussion, pp. 311-12.

42 This text is stored in the Louvre, where it is designated AO 4462. It was published by J. Nougayrol, 'Une version du "Juste Souffrant", $R B 59$ (1952), 23950. More recently it has been translated by Foster in Hallo and Younger, 1.485-95, as well as W.G. Lambert, 'A Further Attempt at the Babylonian "Man and His God", in F. Rochberg-Halton, ed., Language, Literature, and History: 
My Lord, I have debated with myself and in my feelings

$[\ldots]$ of heart: the wrong I did I do not know! 43

Originally, this poem was thought to be a complaint from a righteous sufferer about unjust punishment. As Lambert observes, this poem may be an admission of guilt, not a denial of it. 44 The sufferer confesses his shortcomings in the fourth stanza, where he draws a contrast between the kindness of the god and his own failings:

How much you have been kind to me, how much

I have blasphemed you,

I have not forgotten. ${ }^{45}$

This general confession fits with his previous expression of ignorance regarding specific offences in lines $12 \mathrm{ff}$., and leads us to question the correctness of classifying this document under the heading of 'Just Sufferer Compositions', ${ }^{46}$ since Lambert has pointed out the move in current thinking away from earlier assessments.

The difference between an innocent sufferer and an ignorant one is subtle but important in the Mesopotamian view. At the end of the document the petitioner is directed to do charitable deeds, which may be seen as a penance (lines 62-65).

In stanza 8 the response of the god to the sufferer is found:

Your disease is under control,

let your heart not be despondent!

The years and days you were filled with misery are over.

How could you have lasted the whole of this grievous illness?

You have seen distress,... is (now) held back.

You have borne its massive load to the end.

They have you, (but) the way is open to you.

The path is straight for you; mercy is granted you.

You must never, till the end of time, forget [your] god,

Your creator, now that you are favored. ${ }^{47}$

Philological and Historical Studies Presented to Erica Reiner (AOS 67; New Haven: AOS, 1987), pp. 187-202.

43 Hallo and Younger, 1.485, lines 12-13.

44 W.G. Lambert, Babylonian Wisdom Literature (Oxford: Clarendon, 1960), pp. 10-11, reading line 14: ú!-[ka-ab-bi-i]s! an-zi-il-la-ka a-na[ku i]k ki-ba-am li-im-na-ma am-x[x] xxxx ('I have trespassed against you, I have...a wicked abomination').

45 Hallo and Younger, 1.485. Recently Lambert has expressed doubt about part of this reconstruction and translation in 'Further Attempt', pp. 191, 195-96, suggesting it to read 'Have I...', making it a request for an explanation rather than a confession.

46 As in Hallo and Younger, 1.485.

47 Hallo and Younger, 1.485. 
The god apparently decided to restore the sufferer and gave a warning to pay more attention to the god. The author has stated ignorance of his sin, yet counted on the god's good will to relieve his pain. In spite of being left in the dark regarding his sins, the author continues to hold to the doctrine of retribution, seeing piety (understood as ritual observance) as the best way to counteract or prevent calamities.

(2) Ludlul bēl Nēmeqi. ${ }^{48}$ This poem's title comes from its opening line which is usually translated 'I Will Praise the Lord of Wisdom', the lord of wisdom being Marduk. It has also been called the 'Poem of the Righteous Sufferer' and 'The Babylonian Job'49 although any comparison with the book of Job fails to appreciate the depth of the problem of suffering in Job, where no definite answer is given..$^{50}$

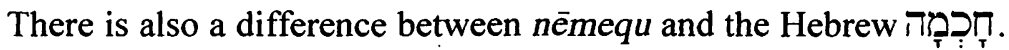
The Akkadian word means the ability to perform an occupation, as does the Hebrew. However, nèmequ is associated with magic rites, incantations, and spells, and rarely used with reference to morals. ${ }^{51}$ The Hebrew term emphasised duties to God in a moral or ethical sense over the observance of ritual, cult magic, incantations or spells, as does nēmequ. Lambert calls חְָָָָ a 'philosophy of life' and cites only a single passage where nēmequ is used with this connotation. 52

Frustration over unresponsive deities and the inability of diviners and priests to determine the cause of the problem was the lot of this sufferer:

48 For introductory matters and an analysis of content see Lambert, BWL, pp. 2127. A recent translation by Foster may be found in Hallo and Younger, 1.486-92.

49 Mattingly, p. 321.

50 See R.E. Murphy, The Tree of Life: An Exploration of Biblical Wisdom Literature (New York: Doubleday \& Co., 1990), p. 156, criticising the position taken by $\mathrm{H}$. Gese, Lehre und Wirklichkeit in der alten Weisheit (Tübingen: J.C.B. Mohr [Paul Siebeck], 1958), p. 63. M. Weinfeld claims 'Man and His God' and Ludlul bēl Nēmeqi have more in common with thanksgiving psalms than with Job; see his 'Job and Its Mesopotamian Parallels-a Typological Analysis' in W. Claasen, ed., Text and Context: Old Testament and Semitic Studies for F.C. Fensham (JSOTSS 48; Sheffield: JSOT Press, 1988), p. 217.

51 Thus Lambert, $B W L$, p. 1; and 'Some New Babylonian Wisdom Literature', p. 32; cf. L. Kalugila, The Wise King (Uppsala: CWK, 1980), who discusses Sumerian and Akkadian expressions for wisdom (pp. 38-39) and cites passages from Enüma elish showing Marduk's tie to incantations, spells, and cult magic (pp. 43-45). In Hebrew, חדְָָָָ is seen as skill in an occupation (e.g. Bezalel, Ex. $31: 1-3)$, just as the Babylonian ummânu refers to manual skills and intellectual talent; see Lambert, 'Some New Babylonian Wisdom Literature', p. 30.

52 'Some New Babylonian Wisdom Literature', p. 31. The passage occurs in Šrpu II.173: 'Siduri...goddess of wisdom' (dištar(15) ni-me-qí); see Reiner, p. 18. 
I called to my god, he did not show his face,

I prayed to my goddess, she did not raise her head.

The diviner with his inspection did not get to the bottom of the matter,

Nor did the dream interpreter with his incense clear up my case.

I beseeched [sic] a dream spirit, but it did not enlighten me,

The exorcist with his ritual did not appease divine wrath. ${ }^{53}$

The sufferer complains that his misfortunes have struck even though he has not been lax in cultic responsibilities:

I, for my part, was mindful of supplication and prayer;

Prayer to me was the natural recourse, sacrifice my rule.

The day for reverencing the gods was a source of satisfaction to me,

The goddess's procession day was my profit and return.

Praying for the king, that was my joy.

His sennet was as if for (my own) good omen.

I instructed my land to observe the god's rites,

The goddess's name did I drill my people to esteem. ${ }^{54}$

Human and divine values seemed inverted, and the ways of the gods were difficult to determine:

I wish I knew that these things were pleasing to a god!

What seems good to one's self could be an offense to a god.

What in one's own heart seems abominable could be good to one's god.

Who could learn the reasoning of the gods in heaven?

Who could grasp the intentions of the gods of the depths?

Where might human beings have learned the way of a god? 55

This apparently innocent sufferer found no comfort in his religion, and may be discretely blaming Marduk for his suffering, though he does this with great delicacy and avoids open accusations. ${ }^{56}$ The gods were silent, the priests were unable to determine the cause of his problems and he had no assurance that keeping the cult actually led to reward. This complaint is followed by a series of statements on the uncertain nature of human existence (II.39-47) and the speaker confesses ignorance of the meaning of it all: 'I have ponde[red] these things; I have made no sense of them. 57

The problem is seemingly relieved in a series of three dreams, following which the illness is taken away and the misfortunes are reversed. Unfortunately the tablet is broken at the very point at which the sufferer's infractions were revealed (III.55-60). In Foster's

53 Hallo and Younger, 1.488; II.4-9; cf. also II.108-113.

54 Hallo and Younger, 1.488; II.23-30.

55 Hallo and Younger, 1.488; II.33-38.

56 Lambert, 'Some New Babylonian Wisdom Literature', pp. 32-34.

57 Hallo and Younger, 1.489; II.48. Also see Lambert's discussion in BWL, p. 22. 
translation 58 only line 60 ('He made the wind bear away my offenses') is still intact. But line 58 has been reconstructed as:

It has become patent to me, my punishment, my crime, (to wit) that I did not revere her (the goddess's) fame. ${ }^{59}$

This line shows that the speaker did not consider himself an innocent sufferer, only a previously ignorant one. He cites his failure to give proper respect to a goddess as one of the reasons for his calamities. If the rest of the text could be reconstructed it would be clear just what caused the god and goddess to send the misfortunes upon this person. If line 58 is in synonymous parallelism with line 57 one can posit another statement of sin cited as cause for the misfortunes. 60

(3) A Sufferer's Salvation (R.S. 25.460). This relatively short (46 lines) Akkadian text was discovered at Ras Shamra and published by J. Nougayrol, who it dates from c. 1300 but says its archaisms push it back as early as the Old Babylonian or early Kassite periods. ${ }^{61}$ The similarities to Ludlul bēl Nēmeqi and the appearance of an Akkadian text at Ugarit are a product of the long-standing cultural contact between Babylon and the Levant. ${ }^{62}$ The author of this text does not grapple with the reasons behind the suffering. ${ }^{63}$ In fact, the surviving opening lines (1-8) indicate that no method of inquiry had been able to produce an answer. ${ }^{64}$ With support from family and friends, the sufferer was encouraged to depend on the mercy of Marduk (lines 924). In the closing lines the sufferer launched into praises for Marduk

\footnotetext{
58 Hallo and Younger, 1.490.

59 I.J. Gelb et al., ed., The Assyrian Dictionary of the Oriental Institute of the University of Chicago (21 vols.; Chicago: University of Chicago Press, 1956-), 4.170: i-pi-a-an-ni in-nin-ti(!) ar-ni la āduru dalīiı̌sa.

60 Synonymous parallelism is displayed in III.50-51, the closest complete lines in the surviving texts and throughout the poem. This is in no way a conclusive argument but it certainly leaves open the possibility, even the likelihood, of a parallel statement.

61 J. Nougayrol, '(Juste) Souffrant, (R.S. 25.460)', Ug 5 (1968), 265-73. See also H-P. Müller, Das Hiobproblem: Seine Stellung und Entstehung in Alten Orient und im Alten Testament (Darmstadt: Wissenschaftliche Buchgesellschaft, 1978), p. 56; and Mattingly, p. 324. Originally referred to simply as R.S. 25.460 , it is now called A Sufferer's Salvation in the translation by Foster in Hallo and Younger, 1.486.

62 Gray, p. 262. Nougayrol, '(Juste) Souffrant', p. 267, says there is the possibility of a common source behind Ludlul and R.S. 25.460.

63 W. von Soden, 'Bemerkungen zu einigen literarischen Texten in Akkadischen Sprache aus Ugarit', UF 1 (1969), 191.

64 There is a gap of about 15 lines at the beginning of the tablet, see Hallo and Younger, 1.486. The text refers to oracles (line 2), haruspicy (3), omens (5), and oneiromancy (6); see Nougayrol, '(Juste) Souffrant', p. 268.
} 
(lines 25-46), who, along with a personal god and goddess, is seen as responsible for the sufferer's pain as well as restoration.

Here, as in other documents, the sufferer, who makes no claim of innocence, seeks a solution to his problems from within the cult, rather than questioning its validity. Until the broken portion of this text is recovered and a claim of innocence is discovered, it is questionable to classify this document under the heading of 'Just Sufferer Compositions'.

(4) Babylonian Theodicy. This work is structured as an acrostic of 27 stanzas, eleven lines each. ${ }^{65}$ It is one of the most developed and sceptical cuneiform texts concerned with divine justice and human suffering. ${ }^{66}$ According to Lambert, this poem was probably written about $1000 \mathrm{BC}$, although von Soden gives a date of about two centuries later. ${ }^{67}$

The author of the poem is identified by the acrostic which translates, 'I Saggil-kinam-ubbib, the incantation priest, am adorant of the god and the king. ${ }^{68}$ It consists of a dialogue between a sceptic and a pious friend.

As the acrostic unfolds the sceptic recites the injustices and difficulties he has experienced, including being orphaned at a young age (lines 9-11), resulting in poor health and destitution (lines 27-33). The pious friend recites what appears to be a proverb of conventional wisdom:

He who looks to his god has a protector,

The humble man who reveres his goddess will garner wealth. 69

The sufferer then points out examples which question the connection between piety and divine reward (lines 48-53), and claims he has not failed to observe the required rituals, which should ward off all the calamities he has endured (lines 54-55). The friend responds with his

65 Lambert, $B W L$, p. 63. For the text see Foster's translation in Hallo and Younger, 1.492-95; for Lambert's translation see $B W L$, pp. 70-91.

66 Mattingly, p. 325.

67 Lambert, $B W L$, p. 63; von Soden, 'Das Fragen', pp. 51-52. For an overview of the entire poem, see Lambert, $B W L$, pp. 64-65.

68 Lambert, $B W L$, p. 63: a-na-ku sa-ag-gi-il-ki-[i-na-am-u]b-bi-ib ma-áš-ma-šu ka-ri-bu ša i-li ú šar-ri.

69 Hallo and Younger, 1.493; cf. $B W L$, p. 70, lines 21-22. Line 21 may be translated 'he who waits on his god has good fortune', a parallel statement to line 22 according to Lambert. For general discussions of the relationship between individuals and protective spirits, including the terms ilu (god), ištaru (goddess), lamassu (angel) and $\breve{s e} d u$, even though the latter term does not occur in these lines, see Jacobsen, Treasures of Darkness, pp. 155-56; and Oppenheim, pp. 198-206. 
dogma that can be summed up as 'piety pays'. ${ }^{70}$ The examples cited by the sufferer-the wild ass who tramples the grain, the lion who attacks livestock and the human profiteer-will all pay the penalty for their crimes in due time (lines 59-64). ${ }^{71}$ Holding his ground, the sufferer stubbornly says:

Those who seek not after a god can go the road of favor, Those who pray to a goddess have grown poor and destitute. Indeed, in my youth I tried to find out the will of (my) god, With prayer and supplication I besought my goddess.

I bore a yoke of profitless servitude:

(My) god decreed (for me) poverty instead of wealth. ${ }^{72}$

The element of prosperity for the wicked has not been mentioned in any work previously examined, ${ }^{73}$ but seems to be one of the most irritating issues to the sufferer in this poem..$^{74}$ The prosperity of the wicked, more than the suffering of the righteous, made the problem so acute. While no one could be sure that an outwardly good person had not secretly or unknowingly offended a god, one could hardly doubt that an obviously bad person deserved punishment. ${ }^{75}$ The friend replied that the ways of the gods are unknowable:

Divine purpose is as remote as innermost heaven,

It is too difficult to understand, people cannot understand it. ${ }^{76}$

The frustration of the sufferer must have been aggravated by the fact that he was an incantation priest, i.e. a religious professional. If anyone should have had an idea of how to reverse suffering it should have been him, or his associates.

The conclusion reached by the friend is that the evil experienced by humankind is not directly due to the injustice of the gods, but to the sin of each individual. When the gods created humanity they

Gave twisted words to the human race.

They endowed them in perpetuity with lies and falsehood. ${ }^{77}$

In other words, people are evil because the gods made them that way. Both sufferer and friend began by assuming divine responsibility for

70 Lambert, 'Some New Babylonian Wisdom Literature', pp. 35-36.

71 Saggs, Encounter, p. 119.

72 Lines 70-75; Hallo and Younger, 1.493.

73 R.J. Williams, 'Theodicy in the Ancient Near East', in J.L. Crenshaw, ed., Theodicy in the Old Testament (Philadelphia: Fortress, 1983), p. 46.

74 Saggs, Encounter, p. 119.

75 Saggs, Encounter, pp. 119-20. Similar issues were confronted in Pss. 37, 49 and 73 , as well as in the book of Job.

76 Hallo and Younger, 1.494.

77 Hallo and Younger, 1.495. 
maintaining justice. They ended up admitting that the gods made people prone to injustice..$^{78}$

The poem ends with the sufferer thanking his friend for his sympathy and with a plea to the personal god and goddess to give help and be merciful, as well as a call for Shamash to guide him..$^{79}$ The problem is never solved in this text. The speakers in this poem had to content themselves with the conclusion that the righteous person did not exist. The justice of the gods was not at issue, since their ways were unknowable; thus it was useless to question them. For this reason the correctness of the commonly used title of the poem can be questioned. The issue of theodicy does not arise in the so-called Babylonian Theodicy.

(5) The Poem of Erra. This poem has received little attention because of its relatively recent recovery and the need to collate many of its text fragments. ${ }^{80}$ However, it was very popular judging by its diffusion over a large geographical area during the first millennium. ${ }^{81}$

The story-line is that humans had offended several gods, including Erra, ${ }^{82}$ Marduk, the Sebitti (or Sebetti) ${ }^{83}$ and the Anunnaki. ${ }^{84}$ The offences included contempt (I.120-21), disrespect (I.122), and cultic

78 Lambert, $B W L$, p. 65 . The quote above contains an idea similar to the statement found in the Sumerian 'Man and His God' quoted above: 'Never has a sinless child been born to its mother,...a mortal(?) has never been perfect(?), a sinless man has never existed from old'; see Hallo and Younger, 1.574.

79 Lines 295-97; Hallo and Younger, 1.495. Shamash is called a shepherd, showing a positive view of the god, or it may be a statement designed to coax the god into helping him.

${ }^{80}$ A recent translation is that of S. Dalley in Hallo and Younger, 1.404-416. Two older works include L. Cagni, Das Erra-Epos: Keilschrifttext (Rome: Pontifical Biblical Institute, 1970); idem, The Poem of Erra (Malibu: Undena, 1977). Previous texts were either incomplete or incompetently handled according to $D$. Bodi, The Book of Ezekiel and the Poem of Erra (OBO 104; Göttingen: Vandenhoeck \& Ruprecht, 1991), p. 13, n. 11.

81 Jacobsen, Treasures of Darkness, p. 227; Bodi, p. 52. For issues of introduction see Bodi's discussion, pp. 54-62; and S. Dalley in Hallo and Younger, 1:404-405.

82 As the text shows in the epilogue (V.39), Erra is also known as Nergal.

83 The Sebitti were seven wicked gods without individual names. They acted as a unit, even to the point of being treated grammatically in the singular. Their cult was widespread in the latter half of the first millennium. In the Erra poem they are exclusively evil, as opposed to Erra and Ishum, who reconstruct the country in the last tablet of the story; see Cagni, Poem of Erra, pp. 18-19.

84 Anunnaki is a Sumerian loanword meaning 'the princely seed'; see Bodi, p. 65, n. 57. For a list of Sumerian evidence for these gods see A. Falkenstein, 'Die Anunna in der sumerische Überlieferung', in H. Guterbock and T. Jacobsen, ed., Studies in Honor of Benno Landsberger on His 75th Birthday (Chicago: University of Chicago Press, 1965), pp. 127-40; for evidence in Akkadian literature see in the same volume B. Kienast, 'Igigu und Anunnaki nach den akkadischen Quellen', pp. 141-58. 
offences (I.127-28). Even animals were holding gods in contempt (I.77) and trampling pastureland (I.83-86). The Anunnaki were deprived of sleep (I.81-82) because of the noise made by mankind, which may be similar in motif to the Atrahasis epic (see above). In the underworld there is a taboo of silence, which if broken, makes it impossible for a mortal to return to the earth unless another person or a god intervenes. ${ }^{85}$

Apparently the gods believed that the increase in the number of humans and the resultant noise posed a direct threat to the gods, that they would be overwhelmed (I.79). Erra mentioned the 'former sin' committed by humans (V.6), no doubt referring to the contempt humans showed Erra (cf. I.120-22). ${ }^{86}$

Stirring up rebellion and war, society was devastated but an assistant, Ishum, interceded on behalf of humanity and calmed Erra down before all of humanity was killed. Ishum then confronted Erra with his indiscriminate killing of both the guilty and innocent:

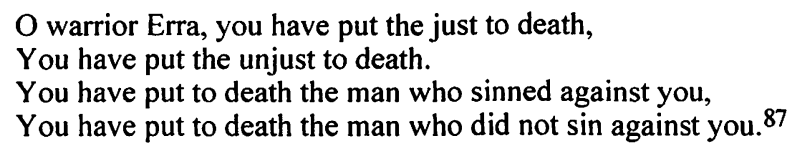

Thus some humans were punished because of sin (hitû) against Erra. The phrase 'to sin against (a deity)' is similar to examples in Akkadian legal documents where it refers to an offence against a suzerain, breaking a treaty, or failing to keep an obligation. ${ }^{88}$ Humans were punished for offending the gods; thus 'noise' made by humans was a crime deserving of punishment. ${ }^{89}$ After Ishum confronted Erra with killing the innocent, Erra decreed that Akkad's enemies would be defeated (IV.128-50), Ishum was honoured (V.1-19) and told to rebuild the city (V.20-38), and blessing was promised to those who honoured the poem (V.39-61).

One of the unique features of the poem of Erra is that the suffering of the innocent is tied directly to one of the gods. To the best of my knowledge this is the only admission by Mesopotamian writers that the concept of an innocent sufferer existed in relation to the gods. The social implications of this are far-reaching. According to Jacobsen,

85 Note Gilgamesh XII.23, 28; cf. S.N. Kramer, 'Death and the Nether World According to the Sumerian Literary Texts', Iraq 22 (1960), 59-68.

86 Bodi, p. 66.

87 IV.104-107; Hallo and Younger, 1.414; cf. Bodi, p. 68; Cagni, Poem of Erra, p. 54.

88 Bodi, p. 68.

89 Cf. Bodi, pp. 131-55. 
the brutalisation of life in the first millennium led to the portrayal of gods as bloodthirsty killers, with the gods now being made in the image of man in a warlike society. 90 He suggests an evolution of the gods from warrior kings, with the image of a protector and ruler in the third millennium to the parental figures of the second millennium. This allowed people to express a personal relationship to the gods. Then it descended to the brutality seen in the Erra poem in the first millennium, showing a slow deterioration of the culture. ${ }^{91}$ While we may doubt that the first millennium was any more brutal than those previous, it may be more accurate to state that associations began to appear in literary works regarding the gods and their responsibility for the suffering and deaths of the undeserving.

To summarise this part of the study, each of the texts examined from Mesopotamia (with the exception of the Erra poem) implies that the sufferer can never claim innocence, only ignorance. Evil was built into humanity; thus suffering was to be expected. ${ }^{92}$ It was simply part of the normal world order; thus there was no need to question and complain. The best course of action was to submit and suffer, and hope that the offended god or goddess would eventually change the course of events. Since the ways of the deities were beyond comprehension, one could never be certain what actions would bring about divine wrath, but it was virtually always certain that the fault lay with the human sufferer, not the deity. Simply stated, there are few instances where suffering is undeserved, and there is no recourse but to admit one's guilt, praise one's god and plead for mercy. ${ }^{93}$

Even worse, there could be no confidence that one could determine the specific offence in any given situation. Even if one recited the $\zeta$ urpu incantations there was no assurance of avoiding sin, and thereby avoiding divine wrath. Everyone merited punishment. Therefore divine punishment of an apparently good person did not call divine justice into question. ${ }^{94}$

\footnotetext{
90 Jacobsen, Treasures of Darkness, p. 227: ' $[1]$ t is the divine that conforms to the image rather than the image that rises up to approach the divine.'

91 Jacobsen, Treasures of Darkness, pp. 223-39, esp. pp. 230-32. This view has some valid points but may be overstated. A look at the Stele of Vultures (c. 2350) shows rather brutal and gruesome scenes of the god Ningirsu cracking the skulls of enemies with a mace. The reverse side shows the dead bodies being scavenged by vultures.

92 Bottéro, 'Problem of Evil', 1.166.

93 M.H. Pope, Job (AB 15, 2nd ed.; Garden City: Doubleday \& Co., 1973), p. 60.

94 Saggs, Encounter, p. 117.
} 
A suffering individual did not disturb the community since national religion and personal religion were thought to operate in separate spheres. The individual distress of a person who was enduring illness or misfortune could be accounted for by those around him on the assumption that this was a private matter between the individual and the personal god. .5

\section{An Assessment of Mesopotamian Literature in Regard to Theodicy}

How do the results of this study compare to von Soden's four elements of theodicy, and what implications do they carry?

1. A Clear Sense of Right and Wrong. A sense of right and wrong is present in Mesopotamia. Humans were held accountable for their sins and crimes, as is evident from the Gilgamesh epic: 'Punish the sinner for his sin, punish the criminal for his crimes (XI.180).' ${ }^{\prime 96}$ This was spoken by the god Enlil, who was mainly responsible for sending the flood. No clear reason was given for the cataclysm at the beginning of the story, nor the end. The absence of a reason for the punishment adds to the overall perception of the inscrutability of the gods, and even more, the gods held humankind to norms of behaviour that they would not reveal and that humans could not discover. ${ }^{97}$ So the sense of right and wrong an individual felt was complicated by an inability to be certain of what fell under those categories in relation to the gods.

Law codes were in effect at various times but these did not explain why a person may experience suffering. The only recourse was to seek the answer through divination, ${ }^{88}$ or to recite the Surpu incantations, hoping to hit upon the one that had offended the deity.

In the event that the gods did not reveal the nature of the offence the claim to 'righteousness' then became a claim that an individual

95 Van der Toorn, p. 114.

96 S. Dalley, Myths from Mesopotamia (Oxford: OUP, 1989), p. 115.

97 W.L. Moran, 'The Gilgamesh Epic', in J.M. Sasson, ed., Civilizations of the Ancient Near East (4 vols.; New York: Scribner, 1995), 4.2334. In Atrahasīs and Erra the reason for destruction is 'noise' (see above), but no reason is offered in Gilgamesh.

98 For a brief look at their divination methods see M.J.A. Horsnell, 'Religions: Assyria and Babylonia', in G. Bromiley, ed., International Standard Bible Encyclopedia (4 vols.; Grand Rapids: Eerdmans, 1979-1988), 4.90; and in more detail, W. Farber, 'Witchcraft, Magic, and Divination in Ancient Mesopotamia', in J.M. Sasson, ed., Civilizations of the Ancient Near East, 3.1895-1909. 
had done all that could be done and the gods had not communicated any failings. ${ }^{99}$ This left a sufferer in ignorance, but there was no assumption of innocence.

2. Significant Individual Worth. People were created to serve the gods, as pointed out earlier, and self-worth came as a result of the role one played in society. The gods needed people. Saggs says:

In the last resort, man was lord of all: the proper functioning of the universe itself depended upon man's maintaining agriculture, supporting the temples, and providing the gods with their sustenance. 100

Saggs may be right in pointing out the importance of humans in their roles which supported a temple and its adjoining property, but there is no sense of 'lordliness' on the part of the average person, especially when it has been observed that people were created to do the work the gods did not want to be bothered with. In contrast to Saggs' claim of lordliness, Bottéro observes the great anxiety in Mesopotamian society evidenced by their obsession with demonic oppression. ${ }^{101}$

The average person in Mesopotamia was not sufficiently significant to the great gods to merit individual attention, thus the heightened importance of the personal deities. ${ }^{102}$ The suffering of an individual was seen as a matter between the individual and the personal god and did not affect the community as a whole. This left a suffering person in an ambiguous position since the gods were not morally obligated to help. ${ }^{103}$ Because humanity existed to serve the gods and do their work, it was only logical to keep people alive and healthy, or so the ancient Mesopotamians reasoned.

3. Conflict between Deities. Given the size of the Mesopotamian pantheon it is amazing that this issue is rarely seen. With so many gods it seems there might have been conflict or competition for the loyalty of worshippers but there is no record of such. Von Soden considers that this fact is due to a virtual monotheism on the practical level of worship, which he called 'monotheotetism' ${ }^{104}$ While it is true that their mythology had instances of conflict between deities ${ }^{105}$ it is very rare to find humans portrayed as victims of the conflict between

\footnotetext{
99 Walton, p. 180.

100 Saggs, Encounter, p. 170.

${ }^{101}$ Bottéro, 'Problem of Evil', 1.163-67, especially 1.165.

102 Saggs, Encounter, pp. 122-123.

103 Van der Toorn, p. 114.

104 Von Soden, 'Das Fragen', p. 46.

${ }^{105}$ E.g. Enūma elish.
} 
gods. An exception to this is Atrahasis, as he was caught in the interplay between Enlil and Enki. 106

4. Judgement in the Afterlife. Without a doubt the ancient Mesopotamians believed in an existence after death. However the evidence is very thin that a judgement would occur. ${ }^{107}$ There are incantation texts which speak of the afterlife in reference to a sick person who is in the land of the dead. ${ }^{108}$ The 'Counsels of Wisdom' speak of the Anunnaki defining the status of the dead. ${ }^{109}$ But the underworld gods did not carry out judgement on the deceased. The fate of the dead depended more on social status, how they died, and the manner in which the funeral rituals were carried out.110 Thus reward and punishment are viewed as something carried out in this life.

Mankind's ultimate destiny was death, as Gilgamesh shows."11 Beyond death was the netherworld ruled by Nergal, or Erra, and his consort Ereshkigal, and inhabited by the disembodied spirits (etemmu) of the dead. Each etemmu experienced a dismal existence in this dark and dreary place where clay and dust were eaten. The twelfth tablet of the Gilgamesh epic lists various unpleasant fates for people but the idea of a blissful afterlife did not exist in Mesopotamia. ${ }^{112}$

\footnotetext{
106 See the discussion in Jacobsen, Treasures of Darkness, pp. 116-21.

${ }^{107}$ See Helmer Ringgren, Religions of the Ancient Near East (tr. J. Sturdy; Philadelphia: Westminster, 1973), pp. 46-48, 121-23; and J. Bottéro, 'La mythologie de la mort en Mésopotamie ancienne', in B. Alster, ed., Death in Mesopotamia (XXVle Rencontre assyriologique internationale; Copenhagen: Akademisk forlag, 1980), pp. 25-52, esp. pp. 29-32, for a discussion of the afterlife in Mesopotamia.

108 Sumerian kur-nu-gi4-a, Akkadian erșet la târi ('land of no return'). The OT knows the earth as the ארץ חיים ('land of the living'), Is. 38:11; 53:8; Je. 11:19; Ps. 27:13; Jb. 28:13; etc., as opposed to the netherworld. Jb. 10:21 observes that this place is a land of gloom and deep darkness from which no one returns. For a detailed study see N.J. Tromp, Primitive Conceptions of Death and the Nether World in the Old Testament (Rome: Pontifical Biblical Institute, 1969).

${ }^{109} B W L$, p. 105, line 147: 'He who fears the Anunnaki extends [his days].' For more on the Anunnaki see the discussion of Erra above.

${ }^{110}$ H.W.F. Saggs, 'Some Ancient Semitic Concepts of the Afterlife', Faith and Thought 90 (1958), 168.

III See the comments of Murphy, pp. 155-56.

112 Horsnell, p. 94.
} 


\section{Conclusion}

The classification of Mesopotamian documents as theodicy in the modern sense is not accurate since divine justice is rarely questioned. This is due in part to the will and purposes of the gods being virtually opaque to humans. Thus the gods conduct themselves by different, and at times, unknown standards.

Since the divine will was difficult to discern, any attempt to discover the sin which had led to suffering depended on proper practice of incantations or divination techniques. Ignorance of the divine will led to the assumption on the part of the Mesopotamians that they 'must have' done something to deserve their suffering. The automatic response in this situation was that of pleading, wailing, and begging for forgiveness so the deity would have pity on them and relieve the suffering. Inherent human sinfulness was justification enough to account for misfortune and sickness. Even in the one document which mentions the suffering of the innocent (Erra) there is no attempt to justify the actions of the god. Innocent people were injured or killed (along with the guilty), and Erra was confronted by a lieutenant, and the two of them helped rebuild the destruction. None of the documents examined in this study attempt to defend divine justice. In Mesopotamia almost all human suffering is assumed to occur as a result of offence against the gods, with the human at fault. Therefore, there is no concept of innocent suffering in Mesopotamia, only ignorance of the cause. 